\title{
THE EXISTENCE OF OVERALL SATISFACTION IN SERVICE CUSTOMER RELATIONSHIPS*
}

\begin{abstract}
Zulganef
Garbarino and Johnson (1999) find that there is no correlation between overall satisfaction and loyalty in the field of customer relationship. Their finding indicates that satisfaction is no longer an important issue in managing service organizations. This research investigates the existence of satisfaction in service organizations, which have relationships with customers. Contrary to Garbarino and Johnson's (1999) finding, this research finds that overall satisfaction, through commitment, has a relationship with loyalty. Hence, customer satisfaction is still a main issue with respect to managing service organizations, especially service organizations that have customer-relationship strategy. Survey method was conducted to test 12 hypotheses, and the sample of this research is customers of credit cardholders and supermarket cardholders. Sample size is 382 consisting of 196 (51.3\%) credit cardholders and $186(48.7 \%)$ supermarket cardholders. Data were analyzed using two-step structural equation modelling technique. In addition, this research also shows that investigators and managers should pay attention to affects, because affects have a unique role in relationship customer behavior.
\end{abstract}

Keywords: affects; commitment; loyalty; overall satisfaction; perceived quality; trust

\footnotetext{
${ }^{*}$ This paper has been proceed in The $1^{\text {st }}$ International Conference on Business and Management Research proceedings, Bali 2006.
} 


\section{Introduction}

Tse and Wilton (1988), Oliva et al. (1992), Taylor and Baker (1994), Fornell etal.(1996), Mittal et al. (1998), Homburg and Giering (2001), and Jones and Suh (2000) find that loyalty is a consequence of overall satisfaction. Their research findings show that the sequential relations between perceived quality, overall satisfaction, and loyalty become a lawlike generalization. In contrast, research by Garbarino and Johnson (1999) finds that purchase intention is not a consequence of overall satisfaction, meaning that overall satisfaction has no relationship with loyalty.

The difference between lawlike generalization and Garbarino and Johnson's (1999) finding enthuse a chance to confirm and replicate the sequential relationship amongst perceived quality, overall satisfaction, and intention to loyalty, especially in the field of customer relationship. Brown and Gaulden, Jr. (1982) and Dharmmesta (1999a) suggest that replication and extension of a research finding is fundamental for theory development. In support for developing a consumer behavioral theory, this study replicates and confirms Garbarino and Johnson's (1999) finding by extending their model.

This research investigates the sequential pattern of relationships amongst perceived quality, overall satisfaction, and intention to loyalty. The pattern has been examined by several researchers, such as Alford and Sherrel
(1996), McDougall and Levesque (2000), Jones and Suh (2000), and Eggert and Ulaga (2002). Alford and Sherrel (1996), McDougall and Levesque (2000), Jones and Suh (2000), and Eggert and Ulaga (2002) find a sequential relationship amongst perceived quality, overall satisfaction, and intention to loyalty. In addition, Mano and Oliver (1993), Oliver(1993), Spreng (1996), and Jones and Suh (2000) define customer satisfaction as overall satisfaction; overall satisfaction as the operational definition of satisfaction is also utilized in this study, and is interchangeable with customer satisfaction.

Garbarino and Johnson's (1999) finding leads to customer satisfaction being no longer a main issue with respect to managing service organizations since customer satisfaction is not an antecedent of intention to loyalty. On the other hand, lawlike generalizations and the research of Alford and Sherrel (1996), McDougall and Levesque (2000), Jones and Suh (2000), and Eggert and Ulaga (2002) reveal that overall satisfaction is still an important issue in managing service organizations.

The second issue addressed in this study is the different findings between Oliver's (1993) and Price et al.'s (1995) research. Oliver's (1993) study in automobile and education industries finds that there is a positive correlation between perceived quality and customer satisfaction, either directly or indirectly mediated by positive or negative affects. On the other hand, Price et al. 
Zulganef-The Existence of 0verall Satisfaction in Service Customer Relationships

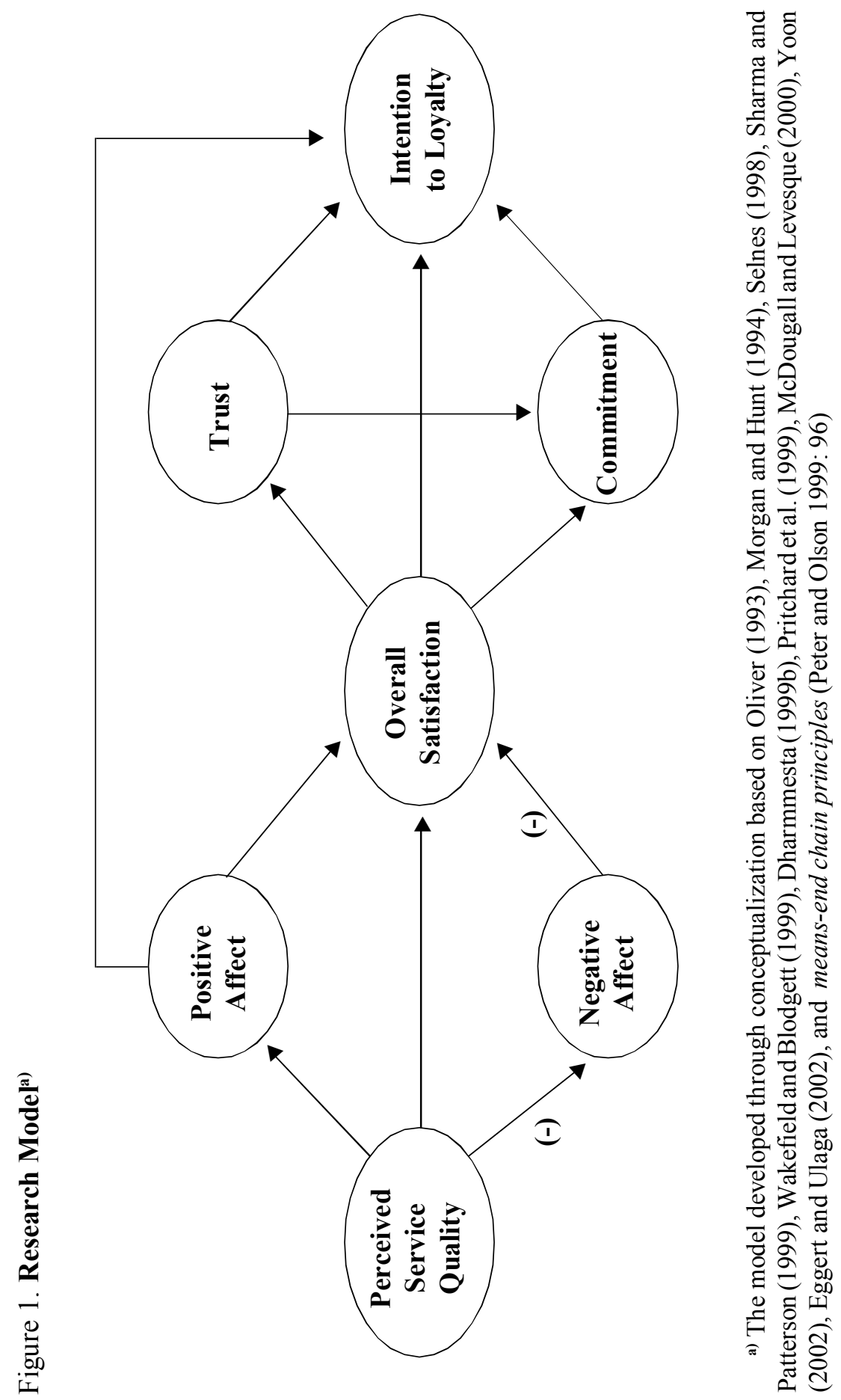


Gadjah Mada International Journal of Business, September-December 2006, Vol. 8, No. 3

(1995), in tourism industry, find that the relationship between perceived quality and customer satisfaction is mediated by positive affects, but not by negative affects. Oliver's (1993) and Price et al.'s (1995) studies raise up conflicting evidence concerning the relationship between overall satisfaction and (intention to) loyalty, and create an opportunity to confirm and replicate the relationship amongst perceived quality, affects, and customer satisfaction. Affects are also known as a fastener in the social relationship as affects can make a social bonding, such as an association between parents and their sons or daughters, and can be determined through stimulus reinforcement (Rolls 1997).

The author develops a model based on Dharmmesta (1999b), Alford and Sherrel (1996), Selnes (1998), Jones and Suh (2000), and Egert and Ulaga (2002). Figure 1 depicts a summary diagram of the proposed model. The model is subsequently used to examine two kinds of service customers, i.e., information processing and possession processing services (Lovelock 2001). Credit card service represents the information processing service whilst supermarkets card service represents the possession processing service. This paper organized as follows: Section 1 provides the introduction to this research, Section 2 discusses literature review, Section 3 shows research design and method, Section 4 documents research findings, and eventually, Section 5 provides conclusions, managerial implications, limitations, and further research.

\section{Literature Review and Hypotheses Development}

\section{Perceived Quality and Overall Satisfaction}

Parasuraman et al. (1988) defines perceived quality as a global judgment or attitude referring to superiority of service. Meanwhile, customer satisfaction is referred to as a specific transaction that has been done by a consumer. Oliver (1993) describes overall satisfaction as a cumulative satisfaction and affection, and Spreng and Olshavsky (1993) measures the overall satisfaction as overall experiences when a consumer buys and uses products.

Overall satisfaction in this study is defined as cumulative satisfaction arising from a specific transaction, for instance, a transaction with supermarket, fitness centre, or auto repair, and is characterized as an affective variable, such as expressed by Parasuraman et al. (1988), Oliver (1993), Spreng and Olshavsky (1993), and Garbarino and Johnson (1999), so that the first hypothesis of this study is based on their research. Their findings show that perceived quality has a positive correlation with overall satisfaction. Referring to their findings and in accord with the objectives of this study (verification and replication), the first hypothesis of this research is: 
Zulganef-The Existence of Overall Satisfaction in Service Customer Relationships

$H_{1}$ : service customer's perceived quality positively influences her overall satisfaction

\section{Affects}

Some writers, such as Mattila (2001), Bagozzi et al. (1999), and Price et al. (1995) describe affects as a customer's emotional response. Bagozzi et al. (1999) defines emotion as follows:

a mental state of readiness that arises from cognitive appraisals of events or thoughts; has a phenomenological tone; is accompanied by physiological processes; is often expressed physically (e.g., in gestures, posture, facial features); and may result in specific actions to affirm or cope with the emotion, depending on its nature and meaning for the person having it.

Rolls (1997) documents that emotion or affects could act as cohesion in the relationship between customer and producer since emotion can create a relationship such as that between a father and his children. Emotion can arise either because of stimuli reinforcement or due to internal arouser (Aaker and Williams 1998; Averill 1980). Studies conducted by Oliver (1993), Price et al. (1995), and Mattila (2001) indicate that emotion arise because of the external stimulation.

Oliver (1993), Price et al. (1995), and Mattila (2001) find that perceived quality has a correlation with positive and negative affects, and in turn, posi- tive and negative affects have a relationship with the overall satisfaction. Hypotheses 2, 3, 4, and 5 are developed predicated on Rolls (1997), Oliver (1993), Price et al. (1995), and Mattila (2001). Rolls (1997) suggests that affects can determine the cohesion between consumers and producers. Oliver (1993), Price et al. (1995), and Mattila (2001) point out that emotion arises because it is stimulated by others and due to service quality that consumers perceive. Accordingly, the second, third, fourth, and fifth hypotheses of this study are as follows:

$H_{2}$ : servicecustomer's perceived quality positively influences her positive affects

$H_{3}$ : servicecustomer's perceived qualitynegatively influences hernegative affects

$H_{4}$ : service customer's positive affects positively influence her overall satisfaction

$H_{5}$ : service customer's negative affects negatively influence her overall satisfaction.

\section{Trust}

Some writers and experts define trust as behavior of relying on the reliability and integrity of others to fulfil their expectation in the future (Moorman et al. 1992; Morgan and Hunt 1994; Mayer et al. 1995; Dorsch et al. 1998; Selnes 1998; Moran and Hoy 1998; Milne and Boza 1999; Van Dyne et al. 2000; Svenson 2001; Wong and Sohal 2002; Ballester and Aleman 2001; and Zineldin and Jonsson 2000). 
Sheth and Parvatiyar (1995) and Selnes (1998) express that a relationship is of high importance in managing service since it can lessen customers' perceived risk of purchase.

Selnes (1998) finds a connection between trust and satisfaction, especially in customer relationship context. Selnes (1998) suggests that satisfaction is a manifestation of an ability of others to fulfil relational norms between buyers and sellers. Selnes's (1998) opinion explicitly describes that trust has a strong relationship with consumer satisfaction. Selnes (1998) also shows that to cafe and restaurant managers in Germany, trust to their suppliers will be enhanced after the managers perceive satisfaction.

According to Selnes (1998), and referring to one of this research's objectives, e.g., to verify overall satisfaction as one of the substantial factors in customer relationship, the sixth hypothesis of this research is:

$H_{6}$ : service customer's overall satisfaction positively influences her trust.

\section{Commitment}

Dwyer et al. (1987), Morgan and Hunt (1994), andPritchard etal.(1998) define commitment as a stable seeking and defensive attitude towards not to change a choice. The definition of commitment given by Dwyer et al. (1987), Morgan and Hunt (1994), and Pritchard et al. (1998) imply that customers want to have a long-term relationship with a product or a producer.
The hypothesis development of overall satisfaction and commitment correlation in this research is based on loyalty steps suggested by Dharmmesta (1999b), Morgan and Hunt (1994), and means-end chain principle suggested by Peter and Olson (1999). Dharmmesta (1999b) reveals four levels and sequence of loyalty: the first is cognitive level, the second is affective level, the third is conative level, and the last is action level. Furthermore, Dharmmesta (1999b) places satisfaction in the affective level, and commitment in the conative or action level. Morganand Hunt (1994) find that overall satisfaction has a positive correlation with commitment, and Peter and Olson (1998) suggest that the objective of consumer's purchase is satisfaction. Based on Dharmmesta's (1999b) idea, Morgan and Hunt's (1994) finding, and means-end chain principle suggested by Peter and Olson (1999), the author makes a hypothesis that the overall satisfaction is the antecedent of consumer commitment. Hence, the seventh hypothesis of this research is:

$H_{7}$ : service customer's overall satisfaction positively influences her commitment.

\section{Trust and Commitment}

Morgan and Hunt (1994) examine the role of trust and commitment in the relationship between tyre distributors. Morgan and Hunt (1999) find that trust and commitment are main variables in the relationship amongst tyre 


\section{Zulganef-The Existence of OverallSatisfaction in Service Customer Relationships}

distributors, providing evidence that trust is an antecedent to arising of commitment.

Sharma and Patterson (1999) express that the trust of professional association members has a positive correlation with members' commitment to making a relationship with the association. Referring to loyalty steps suggested by Dharmmesta (1999b), Morgan and Hunt's (1994) finding, Sharma and Patterson's (1999) work, and one of this research's objectives, e.g., to confirm the relationship between trust and commitment, the eighth hypothesis of this study is:

$H_{8}$ : service customer's trust positively influences her commitment.

\section{Intention to Loyalty}

Intention to behavior is defined as a subjective probability to act certain behavior (Fishbein and Ajzen 1975). Fishbein and Ajzen (1975) further describe that intention can be connected to four different dimensions: (1) behavior, (2) behavioral target, (3) behavioral situation, and (4) behavioral time. Dharmmesta (1999b) - cited Mowen and Minor - defines loyalty as a condition when consumers have a positive attitude towards a brand, are committed to the brand, and are intended to continue purchasing in the future.

A number of researchers (Dick and Basu 1994; Pritchard et al. 1999; Homburg and Giering 2001; and Thiele and Mackay 2001) state that there are two kinds of loyalty: (1) attitudinal loyalty and (2) behavioral loyalty. Thiele and MacKay (2001) define behavioral loyalty as a consumer's actual purchase observed by researchers in a certain period of time. Meanwhile, attitudinal loyalty is defined as favor, commitment, or intention to repurchase usually observed or measured through survey method.

Pritchard et al. (1999) find that loyalty can be measured either through repurchase intention or through the amount of goods purchased by consumers. The former is known as measuring attitudinal loyalty whilst the latter is called measuring behavioral loyalty. Some authors (Pritchard et al. 1999; Homburg and Giering 2001; and Thiele and Mackay 2001) use intention to repurchase to determine the variable loyalty. Hence, according to a number of researchers above, repurchase intention is considered the operational definition of loyalty. However, Fishbein and Ajzen(1975), Ajzen and Fishbein (1980), and Ajzen (1988) explain the theory of reasoned action and the theory of planned behavior, and reveal that intention to behavior is actually a mediating variable between attitude toward behavior and individual actual behavior.

The theory of reasoned action and the theory of planned behavior described by Fishbein and Ajzen (1975), Ajzen and Fishbein (1980), and Ajzen (1988) bring up an issue that attitudinal loyalty could not be operationalized by repurchase intention since intention is different from attitude. Intention is a mediating variable between 
Gadjah Mada International Journal of Business, September-December 2006, Vol. 8, No. 3

attitude and behavior. Accordingly, in this research, loyalty is operationalized by intention to loyalty, corresponding to McDougall and Levesque's (2001) definition of loyalty. In this study, intention to loyalty is defined as a subjective probability that consumers would be loyal (such as to repurchase, recommend products to others, or make positive words of mouth).

To construct the relationship amongst overall satisfaction, trust, and commitment with intention to loyalty, this research uses the findings of Crosby et al. (1990), Alford and Sherrell (1996), Pritchard et al. (1999), Moon (2000), McDougall and Levesque (2000), and Yoon (2002). Alford and Sherrell (1996) find that consumer satisfaction of a dentist would raise repeat patronage intention. Pritchard et al. (1999) find a correlation between commitment and repurchase intention of hotel and airline consumers.

Moon (2000) and Yoon (2002) document that overall satisfaction, trust, and commitment of on-line customers are significantly correlated to their intentions to make future interactions with sellers. McDougall and Levesque (2000) find that overall satisfaction of dentists, auto repairers, hair stylists, and restaurant consumers have a positive consequence to the intention to loyalty and a negative consequence to the intention to switch to other sellers. Referring to Crosby et al. (1990), Alford and Sherrell (1996), Pritchard et al. (1999), Moon (2000), McDougall and Levesque (2000), and
Yoon (2002), that overall satisfaction, trust, and commitment of consumers have a correlation with the intention to loyalty, then the ninth, tenth, and eleventh hypotheses of this research are as follows:

$H_{9}$ : service customer's overall satisfaction positively influences her intention to loyalty

$H_{10}$ : service customer's trust positively influences her intention to loyalty

$H_{11}$ : service customer's commitment positively influences her intention to loyalty

\section{Positive Affects and Intention to Loyalty}

Wakefield and Blodgett's (1999) research on baseball game consumers shows that emotion (excitement) has a positive relationship with repurchase intention pattern. The finding of Wakefield and Blodgett (1999) indicates that consumer affects as a consequence of perceived quality can influence the repurchase intention without being mediated by overall satisfaction.

Wakefield and Blodgett's (1999) finding is on the contrary to Alford and Sherrell's (1996) work. Alford and Sherrell (1996) show that affects are a mediating variable between perceived quality and repurchase intention. These different results of the two studies motivate this research to reinvestigate the relationship between the positive affects and the intention to loyalty. Based on the conflicting results, this 
Zulganef-The Existence of Overall Satisfaction in Service Customer Relationships

research constructs the twelfth hypothesis:

$H_{12}$ : service customer's positive affects positively influence her intention to loyalty.

\section{Research Design}

\section{Sample and Population}

A survey was used to test all hypotheses. The survey was conducted through respondents who have membership in business organizations, such as credit cardholders and supermarket cardholders. The rationale behind the use of survey method is that the data are ex-post facto, testing some hypotheses, and drawing conclusions from experiences or behavior the respondents have acted (Singh 1986; Neuman 2003). Sample size was not statistically defined because sampling method utilized in this study was purposive sampling method (Singh 1986). A total of 426 questionnaires were returned, and 382 of them were considered usable. Amongst the 382 usable questionnaires, 196 (51.3\%) represented credit cardholders and 186 (48.7\%) represented supermarket cardholders.

All variables in this study were measured by multi-item scales, and operationalized based on previous research, such as Zulganef(2002), Cronin and Taylor (1992), and Garbarino and Johnson (1999). Questionnaire items were discussed with and examined to respondents who have relationships (cardholders) with one or two producers before being distributed by some trained research assistants. To overcome some sampling errors, such as ceiling effect, data collection mode bias, measurement timing method, and common method variance (Peterson 1992; Pedhazur and Schmelkin 1991), gifts were given to respondents who had completed the questionnaires.

\section{Results}

\section{Respondent Profiles}

ANOVA was conducted to examine the difference in variables of credit cardholders and supermarket cardholders. The test shows that only negative affects are significantly different. The other variables show no difference either in credit cardholders or in supermarket cardholders. Data collection mode bias was not found in this study. This finding indicates that door-to-door data collecting method has no difference from on-the-spot collecting method. It is also detected that the data in this research are not normal.

Collected data were analyzed through two-step structural equation model. Measurement model harnessed to estimate the structural model was firstly developed through unidimensionality test, especially to find a congeneric measurement model (Anderson and Gerbing 1988; Hair et al. 1995). The measurement model was established using the means of composite numbers.

Cronbach's alpha was subsequently utilized to examine the reli- 
Gadjah Mada International Journal of Business, September-December 2006, Vol. 8, No. 3

ability of questionnaires. The Cronbach's alphas of variables range from 0.768 to 0.80 . Validity test was conducted through convergent validity and discriminant validity referring to Hair et al. (1995) and Chau (1997). All analyzed variables have sufficient convergent validity.

\section{Data Analysis}

Two-step structural equation model was used to analyze the collected data. The results of analysis are shown in Table 1. The first column of Table 1 is the fit indices scores of overall sample, the second column shows supermarket's fit indices scores, and the third column describes credit card's fit indices scores. The results indicate that the investigated model fits the data, meaning that the model is empirically supported by the data. For instance, the scores of GFI (Goodness of Fit Index), TLI (Tucker Lewis' Index), and CFI (Comparative Fit Index) exceed 0.9 , and residual means root (RMR) between the model and the data is less than 0.08 for all samples.

Table 2 depicts the scores of probability and coefficients of regression of hypothesized models for all samples. As can be seen in Table 2, there are seven significant relationships out of 12 hypothesized relationships. It means that 58 percent of correlations in this study are empirically substantiated by the data. The overall sample models supported by 58 percent of empirical

Table 1. Fit Indices Scores of Overall, Supermarket, and Credit-card Samples

\begin{tabular}{|c|c|c|c|}
\hline & Overall & Supermarket & Credit-card \\
\hline Chi-square & 50.772 & 24.245 & 40.819 \\
\hline $\mathrm{P}$ & 0.004 & 0.004 & 0.000 \\
\hline $\mathrm{Cmin} / \mathrm{df}$ & 5.641 & 2.694 & 4.535 \\
\hline GFI & 0.962 & 0.960 & 0.943 \\
\hline AGFI & 0.883 & 0.877 & 0.824 \\
\hline PGFI & 0.309 & 0.309 & 0.303 \\
\hline RMR & 0.024 & 0.030 & 0.022 \\
\hline RMSEA & 0.110 & 0.096 & 0.135 \\
\hline TLI & 0.926 & 0.951 & 0.884 \\
\hline CFI & 0.968 & 0.979 & 0.950 \\
\hline
\end{tabular}


Zulganef-The Existence of OverallSatisfaction in Service Customer Relationships

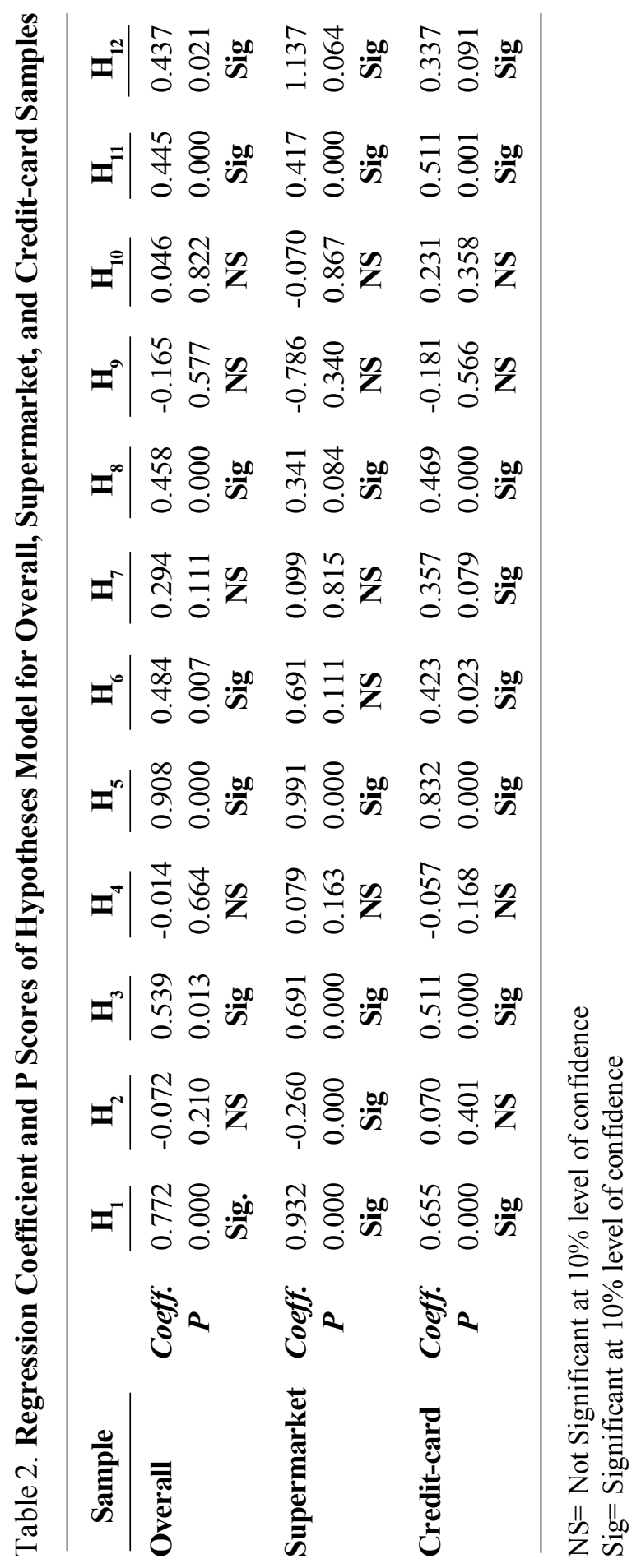


data are presented in Figure 2. Figure 2 shows that both overall satisfaction and commitment have an important role in determining customers' intention to loyalty in service customer relationship

The overall sample models in Figure 2 show that both trust and commitment in customer relationship service will arise as a consequence of customer satisfaction. Furthermore, the overall sample models show that commitment has a role in creating intention to loyalty; however, that role is determined by preceding variable (antecedent variable), which is overall satisfaction. Hence, this research finds that both overall satisfaction and commitment are essential to customers who have relationships with producers, since trust and commitment will arise in the wake of customer satisfaction.

Regression coefficient scores of supermarket sample as shown in Table 2 and Figure 3 indicate that trust and commitment do not have an important role in determining the intention to loyalty. It is suspected that the degree of relationship existing in supermarket respondents is meagre; indicating that membership for supermarket customers does not create customer consistency-commitment (Kardes 2000).

Table 2 also figures some creditcard sample regression coefficients. It is apparent that there are four hypotheses not supported by empirical data in the credit card sample. Figure 4 shows the hypothesized relationships which are supported and not supported by the empirical data in credit card sample. It can be observed in Figure 4 that for the credit cardholders, perceived service quality (perceived product attributes) leads to overall satisfaction and positive affects. Besides, the overall satisfaction raises trust and commitment, and eventually commitment leads to the intention to loyalty. 
Zulganef-The Existence of OverallSatisfaction in Service Customer Relationships

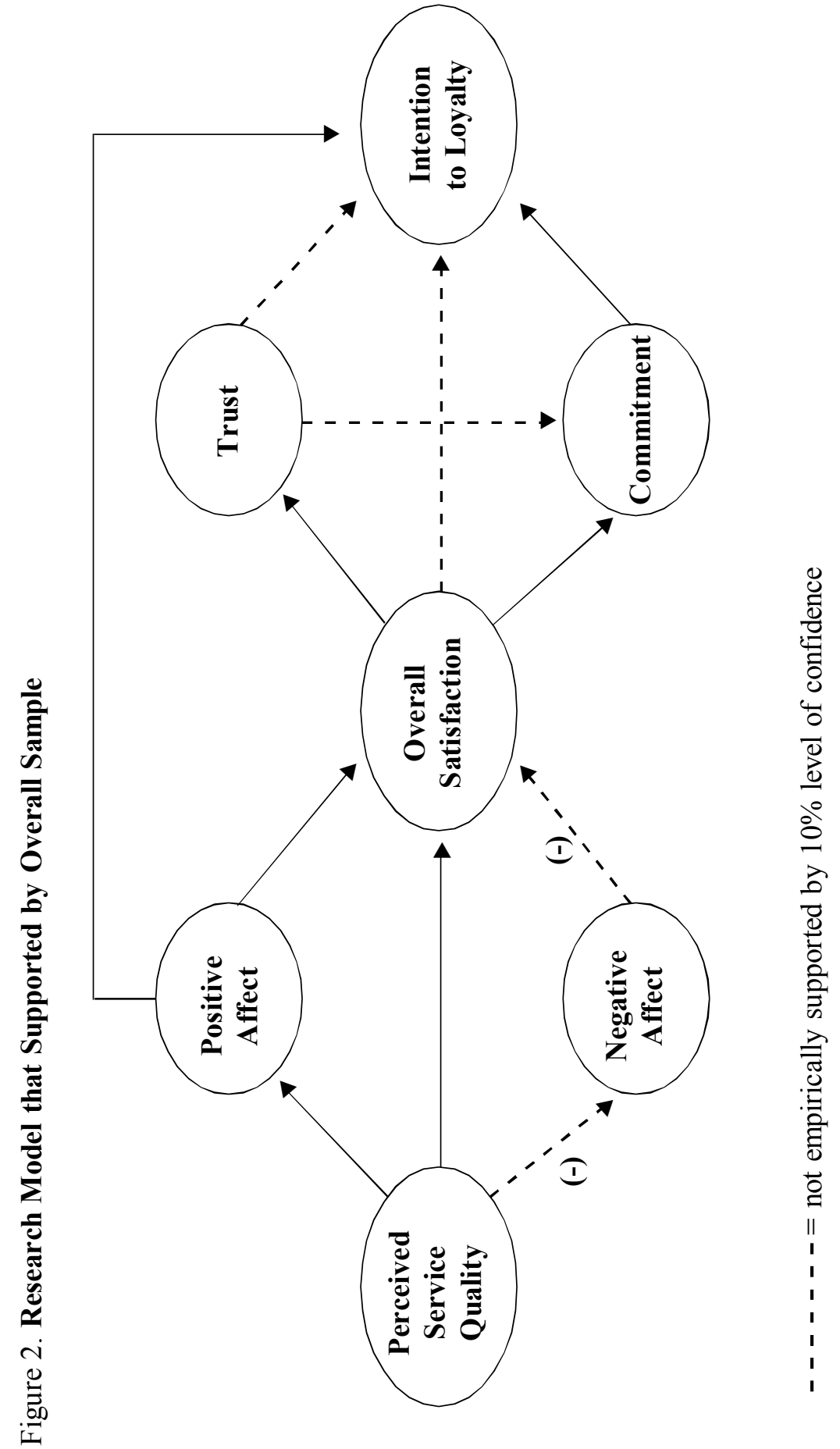


Gadjah Mada International Journal of Business, September - December 2006, Vol. 8, No. 3

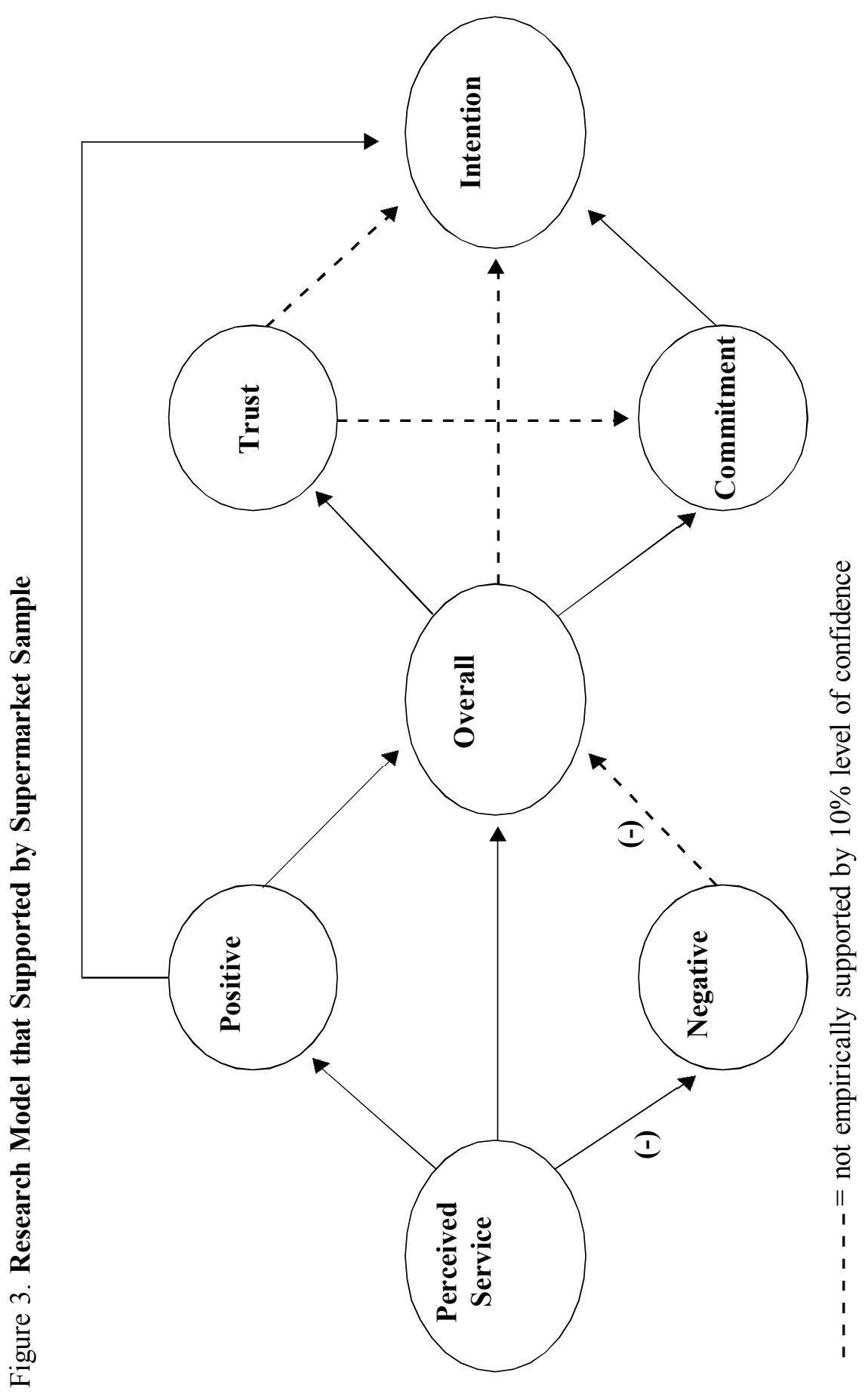


Zulganef-The Existence of Overall Satisfaction in Service Customer Relationships

\section{Conclusions, Limitations, and Research Implications}

\section{Conclusions}

This research substantiates the existence of overall satisfaction, sequential pattern of perceived quality, overall satisfaction, and intention to loyalty as a lawlike generalization. This finding indicates that overall satisfaction has a significant role in customer relationship since overall satisfaction is an antecedent of trust and commitment variables. Moreover, commitment has a significant correlation with intention to loyalty; therefore, it supports the pattern of lawlike generalization.

For the supermarket sample, overall satisfaction and trust do not raise the intention to loyalty, whilst commitment has a significant correlation with the intention to loyalty. However, commitment is neither raised by trust nor by overall satisfaction, accordingly the sequential pattern of lawlike generalization is not supported for the supermarket sample. Nevertheless, perceived quality through positive affects has a correlation with the intention to loyalty. It means that positive affects have a crucial role in determining the intention to loyalty.

For the credit card sample, overall satisfaction has a significant role with respect to customer relationship. It is shown in Figure 4 that not only is overall satisfaction an antecedent of trust and commitment, but it also, together with trust, raises commitment, and commitment eventually determines the intention to loyalty.

The investigation of sample above (overall, supermarket, and credit card) also reveals that positive affects have a positive correlation with the intention to loyalty. This fact evidences that in customer relationship, positive affects have a role in determining the intention to loyalty. This role indicates that positive affects are so important a variable in the field of customer relationship that service managers and investigators should pay attention to it.

\section{Limitations and Further Research}

This research has three limitations. The first is the types of service. Four conclusions are drawn from two kinds of service only, e.g., information processing service (credit card) and possession processing service (supermarket). Hence, the sampling method cannot generalize the results of this study; it may be retested to other types of service, such as mental processing service (theatre or cinema) and people processing service (hairdressing or beauty salon).

The second limitation is the types of credit card. This study does not make any distinction amongst credit card types. There are several types of credit card by which holders have dissimilar behavior, such as platinum, gold, and silver cards. In the future, researchers had better divide creditcard respondents into platinum, gold, and silver card respondents. 
Gadjah Mada International Journal of Business, September-December 2006, Vol.8, No. 3

The last limitation is the possible biloyalty of respondents. This research does not divide respondents into single cardholders and multi-cardholders; consequently, this study cannot identify the respondents whether they have single loyalty or biloyalty.

\section{Research Implications}

This research has implications both to theory and to practice. Theoretically, first, this research contributes to the development of consumer behavior theory through the understanding that trust and commitment are not the only important variables to be analyzed in the field of customer relationship, but overall satisfaction should also be taken into account. Moreover, overall satisfaction is still the main issue in service management.

The second contribution of this study to consumer behavior theory development is in the form of model development that brings in affects variable. This study shows that affects, especially positive affects, should be brought into the customer relationship analysis because positive affects in certain condition (for supermarket consumers) could replace the role of trust and commitment in shaping customer loyalty.

The third contribution of this study to consumer behavior theory development is in the substantiation to loyalty stepladder theory. This research has shown that consumer loyalty occurs sequentially through cognitive, affective, and conative phases.

The fourth contribution of this study to consumer behavior theory development is in the comprehension that the relationship between consumers and producers is distinct according to the types of service. For information processing service (for instance, credit card), trust and commitment have a significant role in determining customer loyalty, whilst in possession processing service (such as supermarket), trust and commitment have no significant role in determining customer loyalty.

There are three practical implications of this study. First, this research indicates that service management, especially credit card management, should pay attention to customer satisfaction since customer satisfaction will raise trust and commitment, which in turn lead to loyalty.

The second practical implication is that supermarket business requires that service management pay more attention to service quality since perceived service quality will raise the negative affects of consumers. Therefore, service management should be able to manage service attributes (service quality dimensions) in such a way that the arrangements can reduce the possibility of raising the negative affects.

The third practical implication is that relationship programs have yet to 


\section{Zulganef-The Existence of OverallSatisfaction in Service Customer Relationships}

be sufficient to create loyalty. Managers should also pay attention to customer satisfaction and emotion, especially for supermarket and credit card managers, as emotion has a direct influence on the intention to loyalty without being mediated either by trust or by commitment.

\section{References}

Aaker, J. L, and P. Williams. 1998. Empathy versus pride: The influence of emotional appeals across cultures. Journal of Consumer Research 25 (December): 241-261.

Ajzen, I., and M. Fishbein. 1980. Understanding Attitudes and Predicting Social Behavior. Englewood Cliffs, New Jersey: Prentice Hall, Inc.

Ajzen, I. 1988. Attitudes, Personality and Behavior. Milton Keynes: Open University Press.

Alford, B. L., and D. L. Sherrell. 1996. The role of affect in consumer satisfaction judgements of credence-based service. Journal of Business Research 37: 71-84.

Anderson, J. C., and D. W. Gerbing. 1988. Structural equation modeling in Practice: A Review and Recommended Two-Step Approach. Psychological Bulletin 103 (3): 411-423.

Averill, J. R. 1980. A constructivist view of emotion. In R. Plutchik and H. Kellerman (eds), Emotion: Theory, Research, and Experience. Orlando: Academic Press, Inc.: 305-337.

Bagozzi, R. P., Y. Yi, and L. W. Phillips. 1991. Assessing construct validity in organizational research. Administrative Science Quarterly 36: 421-458.

Bagozzi, R. P., M. Gopinath, and P. U. Nyer. 1999 The role of emotions in marketing. Journal of the Academy of Marketing Science 27 (2): 184-206.

Ballester, E. D., and J. L. Munuera-Aleman. 2001. Brand trust in the context of consumer loyalty. European Journal of Marketing 35 (11) (12): 1238-1258.

Berry, L. L. 1995. Relationship marketing of service- Growing interest, emerging perspectives. Journal of the Academy of Marketing Science 23 (4): 236-245.

Brown, S. W., and C. F. Gaulden, JR. 1982. Replication and theory development. In C. S. Lamb and P. M. Dunne (eds), Theoritical Developments in Marketing. Chicago, Ill.: American Marketing Association: 240-243.

Chau, P. Y. K. 1997. Reexamining a model for evaluating information center success using a structural equation modeling approach. Decision Sciences (28)(2) (Spring): 309-334.

Cronin, J. J, and S. A. Taylor. 1992. Measuring service quality: A reexamination and extension. Journal of Marketing 56: 40-55.

Crosby, L. A., K. R. Evants, and D. L. Cowles. 1990. Relationship quality in service selling: An interpersonal influence perspective. Journal of Marketing 54 (July): 6881 . 
Gadjah Mada International Journal of Business, September -December 2006, Vol. 8, No. 3

Dharmmesta, B. S. 1998. Theory of planned behaviour dalam penelitian sikap, niat dan perilaku konsumen. Kelola 18 (VII): 85-103.

Dharmmesta, B. S. 1999a. Riset konsumen dalam pengembangan teori perilaku konsumen dan masa depannya. Jurnal Ekonomi dan Bisnis Indonesia 14 (1): 60-70.

Dharmmesta, B. S. 1999b. Loyalitas pelanggan: Sebuah kajian konseptual sebagai panduan bagi peneliti. Journal Ekonomi dan Bisnis Indonesia 14 (3): 73-88.

Dorsch, M. J., S. R. Swanson, and S. W. Kelley. 1998. The role of relationship quality in the stratification of vendors as perceived by customers. Journal of the Academy of Marketing Science 26 (2): 128-142.

Dwyer, F. R., P. H. Schurr, and S. Oh. 1987. Developing buyer-seller relationships. Journal of Marketing 51 (April): 11-27.

Eggert, A., and W. Ulaga. 2002. Customer perceived value: A substitute for satisfaction in business markets? Journal of Business and Industrial Marketing 17 (2) (3): 107 118.

Fishbein, M., and I. Ajzen. 1975. Belief, Attitude, Intention and Behavior: An Introduction to Theory and Research. Reading, Massachusetts: Addison-Wesley Publishing Company.

Fishbein, M., I. Ajzen, and R. Hinkle. 1980a. Predicting and understanding voting in American elections: Effects of external variables. In I. Ajzen and M. Fishbein, Understanding Attitudes and Predicting Social Behavior. Englewood Cliffs, New Jersey Prentice: Hall, Inc.

Fishbein, M., J. J. Jaccard, A. B. Davidson, I. Ajzen, and B. Loken. 1980b. Predicting and understanding family planning behaviors: Beliefs, attitudes, and intentions. In I. Ajzen and M. Fishbein. Understanding Attitudes and Predicting Social Behavior. Englewood Cliffs, New Jersey: Prentice Hall, Inc.

Fornell, C., M. D. Johnson, E. W. Anderson, J. Cha, and B. E. Bryant. 1996. The American customer satisfaction index: Nature, Purpose, and findings. Journal of Marketing 60 (October): 7-18.

Garbarino, E., and M. S. Johnson. 1999. The different roles of satisfaction, trust, and commitment in customer relationships. Journal of Marketing 63 (April): 70-87.

Gundlach, G. T., and P. E. Murphy. 1993. Ethical and legal foundations of relational marketing exchanges. Journal of Marketing 57 (October): 35-46.

Hair, J. F., R. E. Anderson, R. L. Tatham, and W. C. Black. 1995. Multivariate Data Analysis with Readings. London: Prentice-Hall International, Inc.

Homburg, C., and A. Giering. 2001. Personal characteristics as moderators of the relationship between customer satisfaction and loyalty - An empirical analysis. Psychology and Marketing 18 (1): 43-66

Hunt, S. D. 1990. Truth in marketing theory and research. Journal of Marketing 54 (July): 1-15

Hunt, S. D. 1991. Modern Marketing Theory: Critical Issues in the Philosophy of Marketing Science. Cincinnati, OH: South-Western Publishing Co. 


\section{Zulganef-The Existence of 0verall Satisfaction in Service Customer Relationships}

Jones, M. A., and J. Suh. 2000. Transaction-specific satisfaction and overall satisfaction: An empirical analysis. Journal of Service Marketing 14 (2): 147-159.

Kardes, F. R. 1999. Consumer Behavior and Managerial Decision Making. Reading, Massachussets: Addison-Wesley.

Kotler, P. 1994. Marketing Management: Analysis, Planning, Implementation, and Control $\left(8^{\text {th }}\right.$ ed.). Englewood Cliffs, New Jersey: Prentice Hall International, Inc.

Lee, H., Y. Lee, D. Yoo. 2000. The determinants of perceived service quality and its relationship with satisfaction. Journal of Service Marketing 14 (3): 217-231.

Lovelock, C. 2001. Service Marketing: People, Technology, Strategy. Upper Saddle River, New Jersey: Prentice Hall.

Mano, H., and R. L. Oliver. 1993. Assessing the dimensionality and structure of the consumption experience: Evaluation, feeling, and satisfaction. Journal of Consumer Research, Vol.20, December, 451-466

Mattila, A. S. 2001. Emotional bonding and restaurant loyalty. Cornell Hotel and Restaurant Administration Quarterly 42 (Issue 6): 73-79.

Mayer, R. C., J. H. Davis, and F. D. Schoorman. 1995. An integrative model of organizational trust. Academy of Management Review 20 (3): 709-734.

McDougall, G. H.G., and T. Levesque. 2000. Customer satisfaction with service: Putting perceived value into the equation. Journal of Service Marketing 14 (5): 392-410.

Milne, G. R., and M. Boza. 1999. Trust and concern in consumers perceptions of marketing information management practices. Journal of Interactive Marketing 13 (1) (Winter): 5-24.

Mittal, V., W. T. Ross, Jr., and P. M. Baldasare. 1998. The asymmetric impact of negative and positive attribute-level performance on overall satisfaction and repurchase intentions. Journal of Marketing 62 (January): 33-47.

Moon, Y. 2000. Intimate exchanges: Using computers to elicit self-disclosure from consumers. Journal of Consumer Research 26 (March): 323-339.

Moorman, C., G. Zaltman, and R. Deshpande. 1992. Relationships between providers and users of market research: The dynamics of trust within and between organizations. Journal of Marketing Research XXIX: 314-28.

Moran, M. T., and W. Hoy. 1998. Trust in schools: A conceptual and empirical analysis. Journal of Educational Administration 36 (4): 334-352.

Morgan, R. M., and S. D. Hunt. 1994. The commitment-trust theory of relationship marketing. Journal of Marketing 58: 20-38.

Neuman, W. L. 2003. Social Research Methods: Qualitative and Quantitative Approaches. Boston: Allyn and Bacon.

Oliva, T. A., R. L. Oliver, and I. C. MacMillan. 1992. A catastrophe model for developing service satisfaction strategies. Journal of Marketing 56 (July): 83-95.

Oliver, R. L. 1993. Cognitive, affective, and attribute bases of the satisfaction response. Journal of Consumer Research 20 (December): 418-430. 
Gadjah Mada International Journal of Business, September-December 2006, Vol. 8, No. 3

Parasuraman, A., V. A. Zeithaml, and L. L. Berry. 1988. SERVQUAL: A multiple-item scale for measuring consumer perceptions of service quality. Journal of Retailing 64 (1) (Spring): 12-40.

Pedhazur, E. J., and L. P. Schmelkin. 1991. Measurement, Design, and Analysis: An Integrated Approach. Hillsdale, New Jersey: Lawrence Erlbaum Associates Publishers.

Peter, J. P., and J. C. Olson. 1999. Consumer Behavior and Marketing Strategy. Boston: McGraw-Hill International Editions.

Peterson, R. A., and W. R. Wilson. 1992. Measuring customer satisfaction: Fact and artefact. Journal of the Academy of Marketing Science 20 (1): 61-71.

Price, L. L., E. J. Arnould, and P. Tierney. 1995. Going to extremes: Managing service encounters and assessing provider performance. Journal of Marketing 59 (April): 83-97.

Pritchard, M. P., M. E. Havitz, and D. R. Howard. 1999. Analyzing the commitmentloyalty link in service contexts. Journal of the Academy of Marketing Science 27 (3): 333-348.

Reichheld, F., and P. Schefter. 2000. E-loyalty: Your secret weapon on the web. Harvard Business Review (July-August): 105-113.

Rolls, E. T. 1997. A theory of emotion and its brain mechanisms. In R. Fuller, P. Noonan Walsh, and P. McGinley(eds.). A Century of Psychology: Progress, Paradigms and Prospects for New Millenium. London: Routledge.

Sejwacs, D., I. Ajzen, and M. Fishbein. 1980. Predicting and understanding weight loss: Intentions, behaviors, and outcomes. In I. Ajzen and M. Fishbein, Understanding Attitudes and Predicting Social Behavior. Englewood Cliffs, New Jersey: Prentice Hall, Inc.

Selnes, F. 1998. Antecedents and consequences of trust and satisfaction in buyer -seller relationships. European Journal of Marketing 32 (3/4): 304-322.

Sharma, N., and P. G. Patterson. 1999. The impact of communication effectiveness and service quality on relationship commitment in consumer, professional service. Journal of Service Marketing 13 (2): 151-170.

Sheth, J. N., and A. Parvatiyar. 1995. Relationship marketing in consumer markets: antecedents and consequences. Journal of the Academy of Marketing Science 23 (4): 255-271.

Singh, A. K. 1986. Tests Measurements and Research Methods in Behavioural Sciences. New Delhi: Tata McGraw-Hill Publishing Company Limited.

Sperber, B. M., M. Fishbein, and I. Ajzen. 1980. Predicting and understanding women's occupational orientations: Factors underlying choice intention. In I. Ajzen and M. Fishbein, Understanding Attitudes and Predicting Social Behavior. Englewood Cliffs: Prentice Hall, Inc.

Spreng, R. A. and R. W. Olshavsky. 1993. A desire congruency model of consumer satisfaction. Journal of the Academy of Marketing Science 21 (3): 169-177. 


\section{Zulganef-The Existence of 0verall Satisfaction in Service Customer Relationships}

Svensson, G. 2001. Extending trust and mutual trust in business relationships toward a synchronised trust chain in marketing channels. Management Decision 39 (6): 431440.

Taylor, S. A., and T. L. Baker. 1994. An assessment of the relationship between service quality and customer satisfaction in the formation of consumers' purchase intentions. Journal of Retailing 70 (2): 163-178.

Tse, D. K., and P. C. Wilton. 1988. Models of consumer satisfaction formation: An extension. Journal of Marketing Research XXV (May): 204-212.

Van Dyne, L., D. Vandewalle, T. Kostova, M. E. Latham, and L. L. Cummings. 2000. Collectivism, propensity to trust and self-esteem as predictors of organizational citizenship in a non-work setting. Journal of Organizational Behavior 21: 2-23.

Wakefield, K. L. and J. G. Blodgett. 1999. Customer response to intangible and tangible service factors. Psychology and Marketing 16 (January) (1): 51-68.

Wong, A., and A. Sohal. 2002. An examination of the relationship between trust, commitment, and relationship quality. International Journal of Retail and Distribution Management 30 (1): 34-50.

Yoon, S. 2002. The antecedents and consequences of trust in online-purchase decisions. Journal of Interactive Marketing 16 (2) (Spring): 47-63.

Zineldin, M., and P. Jonsson. 2000. An examination of the main factors affecting trust/ commitment in supplier-dealer relationships: An empirical study of the Swedish wood industry. The TQM Magazine 2 (4): 245-265.

Zulganef. 2002. Hubungan antara sikap terhadap bukti fisik, proses, dan karyawan dengan kualitas keterhubungan, serta perannya dalam menimbulkan niat ulang membeli dan loyalitas. Jurnal Riset Ekonomi dan Manajemen (September): 98-115. 